\title{
Ovarian radiographic and direct measurements of Japanese Quail (Coturnix coturnix japonica) submitted to light restriction
}

\author{
[Medidas ovarianas radiográficas e diretas de codorna-japonesa (Coturnix coturnix japonica) \\ submetida à restrição luminosa]

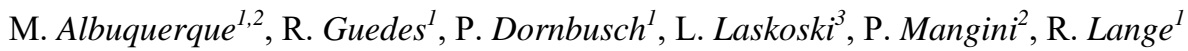 \\ ${ }^{1}$ Universidade Federal do Paraná - Curitiba, PR \\ ${ }^{2}$ Vida Livre Medicina de Animais Selvagens - Curitiba, PR \\ ${ }^{3}$ Universidade Federal do Acre - Rio Branco, AC
}

\begin{abstract}
Often, in pet birds, any stimulus to lay eggs is unwanted in order to reduce reproductive diseases and disorders. The objectives of this study were: to determine the time necessary to promote ovary involution after an eight hour photoperiod using laying Japanese quails (Coturnix coturnix japonica); to connect the ovarian radiographic measurements with egg production; and to compare these measurements with direct ovary data obtained at necropsy. Birds were separated into three groups: $12 \mathrm{~h} / 24 \mathrm{~d}$ (control group $-12 \mathrm{~h}$ photoperiod for 24 days), $8 \mathrm{~h} / 24 \mathrm{~d}$ and $8 \mathrm{~h} / 36 \mathrm{~d}$ (8h photoperiod for 24 and 36 days). After euthanasia, all cadavers were $\mathrm{x}$-rayed to measure ovary length and height. Birds were necropsied to measure ovarian length and weight. Results: radiographic ovary length demonstrated strong and positive correlation $(\mathrm{r}=0.96)$ with direct ovary length of all three groups; laying quails showed higher ovary height $(\mathrm{p}=0.025)$ and length $(\mathrm{p}=0.009)$ than non-laying quails; eight hours of artificial light per day promotes ovary length $(p=0.025)$ and weight $(p=0.009)$ reduction. Conclusions: radiography can estimate the ovary measure and indicate posture; an eight hour photoperiod of 24 days is not enough to promote ovarian regression, while the use of reduced photoperiod for 36 days promotes significant ovary involution.
\end{abstract}

Keywords: avian, photoperiod, gonad, laying, radiography

\section{RESUMO}

Em aves de estimação, geralmente se opta pela redução de estímulos para a postura de ovos visando reduzir a ocorrência de doenças e alterações reprodutivas. Os objetivos deste estudo foram: determinar o tempo necessário para a involução ovariana após um fotoperíodo de oito horas de iluminação usando codornas-japonesas (Coturnix coturnix japonica) na fase de postura; relacionar as medidas radiográficas com a postura de ovos; e comparar estas com as medidas diretas obtidas à necropsia. As aves foram divididas em três grupos: 12h/24d (controle - fotoperíodo de 12 horas por 24 dias), 08h/24d e 08h/36d (fotoperíodo de oito horas por 24 e 36 dias). Após a eutanásia, os cadáveres foram radiografados para mensuração do comprimento e da altura do ovário. Foi efetuada a necropsia para aferição das medidas e pesagem dos ovários. Os resultados mostraram que: o comprimento ovariano obtido por meio de imagem radiográfica apresentou forte correlação positiva $(r=0,96)$ com $o$ comprimento direto do ovário das aves dos três grupos; as aves em período de postura apresentaram maiores medidas de altura do ovário $(P=0,025)$ e comprimentos ovarianos $(P=0,009)$ do que as aves fora de postura; a restrição de luminosidade com oito horas diárias de luz artificial promoveu redução do comprimento ovariano $(P=0,025)$ e da massa ovariana $(P=0,009)$. Conclusões: a radiografia pode estimar a medida do ovário e indicar postura; um fotoperíodo de oito horas de luz por 24 dias não é satisfatório para obter uma regressão ovariana, enquanto 36 dias com o fotoperíodo reduzido promovem uma significativa redução ovariana.

Palavras-chave: ave, fotoperíodo, gônada, postura, radiografia

Recebido em 30 de julho de 2016

Aceito em 10 de outubro de 2016

E-mail: marciahelenavet@yahoo.com.br 


\section{INTRODUCTION}

Most bird species have periodic reproductive cycles and light availability is the external stimulus that most affects this cycle (Olanrewaju et al., 2006; Pereira, 2014). The effect of luminous stimulation on bird reproductive systems is well known (Pezoa Poblete et al., 2013) and it is used in poultry science to enhance egg production (Dominoni et al., 2013). In domestic birds; however, laying eggs can be a disadvantage, since there are many reproductive tract diseases and disorders due to excessive egg laying, such as cloacal prolapse, egg binding, soft-shelled or partially formed eggs, calcium deficiency and behavior changes (Echols, 2002).

Artificial lighting may interfere with the normal annual light cycle and result in inappropriate hormonal cycling, which may lead to excessive egg laying and other problems (Bowles, 2002). Hormonal treatments have been used to stop egg laying, but do not do so permanently (Pye et al., 2001). Husbandry changes should include decreasing the photoperiod to $8-10$ hours of light per day (Bowles, 2002; Rosen, 2012), but there is a lack of useful information to determine the efficacy of this procedure. Some factors can mask the results, such as the type of lighting (incandescent, high frequency or low frequency fluorescent light) (Evans et al., 2012) and light intensity during the day and at night. At night, very low light intensities (0.3 lux) can affect bird's seasonal cycles (Kempenaers et al., 2010; Dominoni et al., 2013).

The objectives of the present study were: to investigate how many days were necessary to promote expressive ovarian regression and stop laying activity in Japanese quail (Coturnix coturnix japonica) exposed to eight hours of light per day; and to take radiographic ovary measurements and direct (real) ovary measurements at necropsy and to compare both measures.

\section{MATERIALS AND METHODS}

The experiment was approved by the Research Ethics Committee of the Federal University of Parana (Number 010/2014) on October $18^{\text {th }}$, 2014.
Eighteen two-year-old, healthy, laying Japanese quail with an weight average of $274 \pm 33$ grams were obtained from the Coturniculture Laboratory of the Federal University of Parana. Birds were marked using nylon cable ties and previously exposed to 16 hours of light per day (12 hours of natural light and 4 hours of incandescent light), receiving laying quail's mash ratio and water ad libitum.

On experimental day zero, quails were brought to the Veterinary Hospital of the Federal University of Parana. Then, birds were housed in pairs in 50 $\mathrm{cm}^{3}$ cages with the same ratio and water ad libitum. The dimensions of the experimental room were $9 \mathrm{~m}^{2}$ wide and $5 \mathrm{~m}$ high. The room was isolated from natural light, so birds were receiving only artificial light from four units of tubular fluorescent of low frequency lamps (40 W). A digital timer switch controlled the illumination period (FDD-60/SB2, G20, Santa Catarina, Brasil). The light intensity was measured at the center of the cage at approximately $22 \mathrm{~cm}$ above the cage floor at different dates. The light intensity was recorded at 220 to 270 lux when the light was on and zero lux when the light was off.

The control group $12 \mathrm{~h} / 24 \mathrm{~d}$ was composed of six animals submitted to $12: 12 \mathrm{~h}$ LD cycle (12 hours of light followed by 12 hours of darkness) for 24 days. Twelve animals were separated in two groups of six animals submitted to $8: 16 \mathrm{~h}$ LD cycle for 24 days (group 8h/24d) and 36 days (group $8 \mathrm{~h} / 36 \mathrm{~d}$ ).

After 24 or 36 days, quails were deeply anaesthesized and killed. Radiographs were taken with digital tecnique (Agfa Healthcare CR-30-X, DS5302, Mortsel, Belgium) with the animals positioned in lateral recumbency using $40 \mathrm{kV}, 100 \mathrm{mAs}$, exposure time of 0.05 seconds and $80 \mathrm{~cm}$ of focal-film distance (Pees, 2008). A penetrometer of $5 \mathrm{~mm}$ stair steps was used to compare the measurements. The radiographic image analyzis was performed by the ImageJ software (NIH Image, Maryland, United States of America), wich allows the insertion of a known distance (penetrometer) to estimate an unknown measure (ovary). Ovarian length was measured from cranial to caudal pole and ovarian height was the distance between dorsal and ventral pole seen in the radiographic image. 
Necropsies were carried out to measure ovarian direct length before removing it. Direct measurement refers to the exact measurement of the ovary at necropsy using instruments. In the present study, a milimetric stainless steel specially manufactured ruler was used with 2 $\mathrm{mm}$ width at its end. Furthermore, the ruler was positioned adjacent to the ovary and a picture was taken to be analysed by the ImageJ software. After ovary removal, it was weighted with a $10 \mathrm{~g}$ capacity and $0.1 \mathrm{~g}$ precision scale (Pesola MicroLine 20010, Baar, Switzerland).

The Graphicpad prisma software was used for statistical analysis (California, United States). Kolmogorov Smirnov test was used to determine whether the data fit with the normal districution. Kruskal-Wallis H test with Dunn's post test was applied for multiple comparison between ovarian length of the three groups. Student's t test was used to compare ovarian weights and ovarian lengths of the $12 \mathrm{~h} / 24 \mathrm{~d}$ (control) and $08 \mathrm{~h} / 36 \mathrm{~d}$ groups, while Mann-Whitney U test was applied to compare ovarian weights and ovarian lengths of the $12 \mathrm{~h} / 24 \mathrm{~d}$ (control group) and $08 \mathrm{~h} / 24 \mathrm{~d}$ groups.

Linear regression tests were performed in order to rule out any interference of the quail's weight in the ovary weight or length. Also using linear regression, the radiographic ovary length was compared to the direct ovary length.

Finally, Student's t test was used to evaluate the relationship between the ovarian radiographic measures (length and height) and egg production. The absence of egg posture was determined by the total absence of eggs in the last 15 days before euthanasia.

\section{RESULTS}

There was little correlation between the quail's weight and ovarian length $(\mathrm{r}=0.11)$ and between the quail's weight and ovarian weight $(\mathrm{r}=0.20)$. The results are disposed on table 1 .

Table 1. Japanese quails' (Coturnix coturnix japonica) radiographic ovarian measures and direct ovarian measures from control group $12 \mathrm{~h} / 24 \mathrm{~h}$ (12 hours of light per day for 24 days) and from light restriction groups $8 \mathrm{~h} / 24 \mathrm{~d}$ ( 8 hours of light per day for 24 days) and $8 \mathrm{~h} / 36 \mathrm{~d}$ ( 8 hours of light per day for 36 days)

\begin{tabular}{cccccc}
\hline Group & $\begin{array}{c}\text { Direct ovarian Ovarian weight } \\
\text { length } \\
(\mathrm{mm})\end{array}$ & $\begin{array}{c}\text { Radiographic } \\
\text { ovarian length } \\
(\mathrm{mm})\end{array}$ & $\begin{array}{c}\text { Radiographic ovarian } \\
\text { height } \\
(\mathrm{mm})\end{array}$ & $\begin{array}{c}\text { Egg } \\
\text { production }\end{array}$ \\
\hline $\mathbf{1 2 h} / \mathbf{2 4 d}$ & & & & & Yes \\
1 & 15.76 & 6.40 & 17.53 & 13.74 & No \\
2 & 22.02 & 0.65 & 23.47 & 17.90 & Yes \\
3 & 33.14 & 7.20 & 34.41 & 18.93 & Yes \\
4 & 21.28 & 4.30 & 23.47 & 12.37 & No \\
5 & 15.79 & 0.75 & 16.65 & 10.01 & Yes \\
6 & 42.13 & 8.75 & 40.66 & 23.37 &
\end{tabular}

$8 h / 24 d$

$\begin{array}{cccccc}1 & 11.87 & 0.20 & \mathrm{X} & \mathrm{X} & \text { No } \\ 2 & 10.51 & 0.10 & \mathrm{X} & \mathrm{X} & \text { Yes } \\ 3 & 12.15 & 0.15 & 14.75 & 8.77 & \text { No } \\ 4 & 14.17 & 0.25 & 16.02 & 5.93 & \text { No } \\ 5 & 29.91 & 10.90 & 28.71 & 12.26 & \text { Yes } \\ 6 & 27.50 & 6.90 & 28.50 & 9.11 & \text { Yes }\end{array}$

\begin{tabular}{|c|c|c|c|c|c|}
\hline $8 \mathrm{~h} / 36 \mathrm{~d}$ & & & & & \\
\hline 1 & 13.55 & 0.15 & $X$ & $X$ & No \\
\hline 2 & 14.60 & 0.75 & $X$ & $\mathrm{X}$ & No \\
\hline 3 & 15.06 & 0.10 & 15.80 & 5.20 & No \\
\hline 4 & 11.83 & 0.05 & 13.66 & 6.51 & No \\
\hline 5 & 11.99 & 0.02 & 13.58 & 8.67 & No \\
\hline 6 & 14.97 & 0.10 & 14.01 & 6.04 & No \\
\hline
\end{tabular}


The comparison among ovarian lengths showed no difference between $12 \mathrm{~h} / 24 \mathrm{~d}$ and $8 \mathrm{~h} / 24 \mathrm{~d}$ groups. However, it demonstrated a difference between $12 \mathrm{~h} / 24 \mathrm{~d}$ and $8 \mathrm{~h} / 36 \mathrm{~d}$ groups (Fig. 1).

The two-group comparison revealed no significant difference between ovarian weight and ovarian length from $12 \mathrm{~h} / 24 \mathrm{~d}$ (control) and $8 \mathrm{~h} / 24 \mathrm{~d}$ groups. The ovarian length mean from $8 \mathrm{~h} / 36 \mathrm{~d}$ group is significantly lower $(\mathrm{p}=0.02)$ than the one from $12 \mathrm{~h} / 24 \mathrm{~h}$ group; as the ovarian weight mean from $8 \mathrm{~h} / 36 \mathrm{~d}$ group is also significantly lower $(\mathrm{P}=0,01)$ than the one from $12 \mathrm{~h} / 24$ group.

There is a strong positive correlation $(\mathrm{r}=0.96)$ between radiographic ovarian length and direct ovarian length (Fig. 2).

The method used to take radiographic measures with Image J is shown in Figure 3.

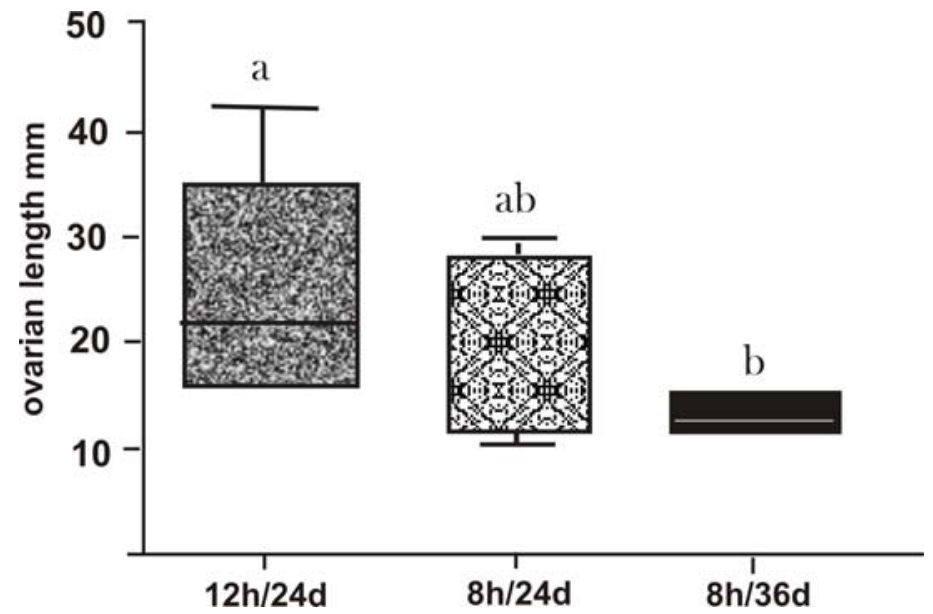

Figure 1. Box-plot graph showing the comparison of ovarian length from $12 \mathrm{~h} / 24 \mathrm{~d}, 8 \mathrm{~h} / 24 \mathrm{~d}$ and $8 \mathrm{~h} / 36 \mathrm{~d}$ groups using Kruskal-Wallis with Dunn's multiple comparison tests. Different letters represent significant difference $(\mathrm{p}<0.05)$ between $12 \mathrm{~h} / 24 \mathrm{~d}$ and $8 \mathrm{~h} / 36 \mathrm{~d}$ groups, while equal letters mean no significant difference between $12 \mathrm{~h} / 24 \mathrm{~d}$ and $8 \mathrm{~h} / 24 \mathrm{~d}$ groups and between $8 \mathrm{~h} / 24 \mathrm{~d}$ and $8 \mathrm{~h} / 36 \mathrm{~d}$ groups. Upwards, rectangle's horizontal lines represent first quartile, median and third quartile. Other horizontal lines exhibit minimum and maximum values.

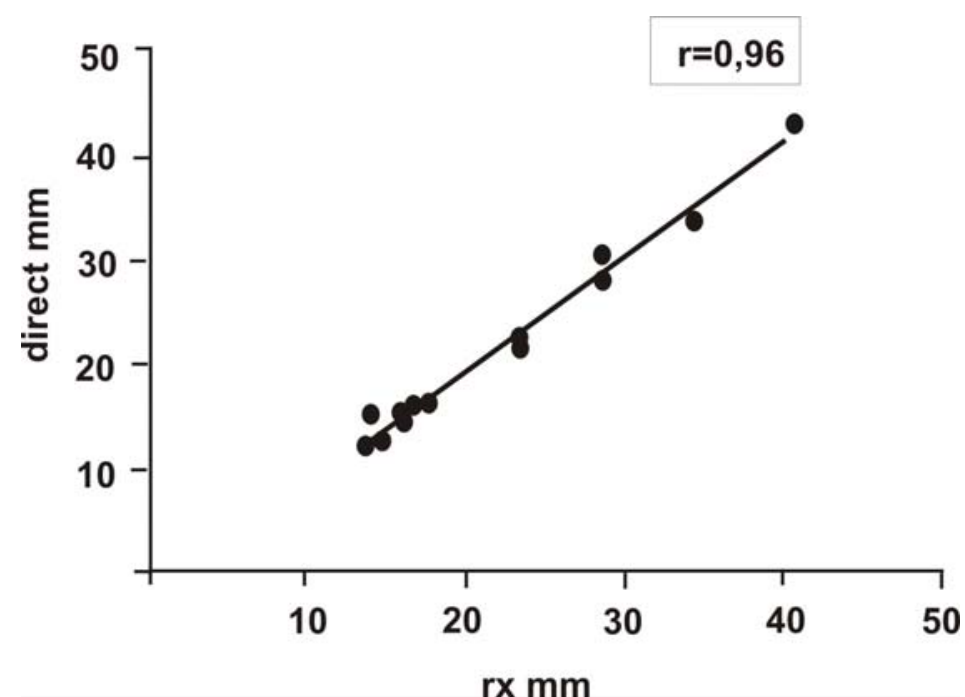

Figure 2. Linear regression graph $(\mathrm{y}=1.07 \mathrm{x}-2.50)$ generated with Graphicpad prisma showing the correlation between radiographic ovarian length and direct ovarian length. 


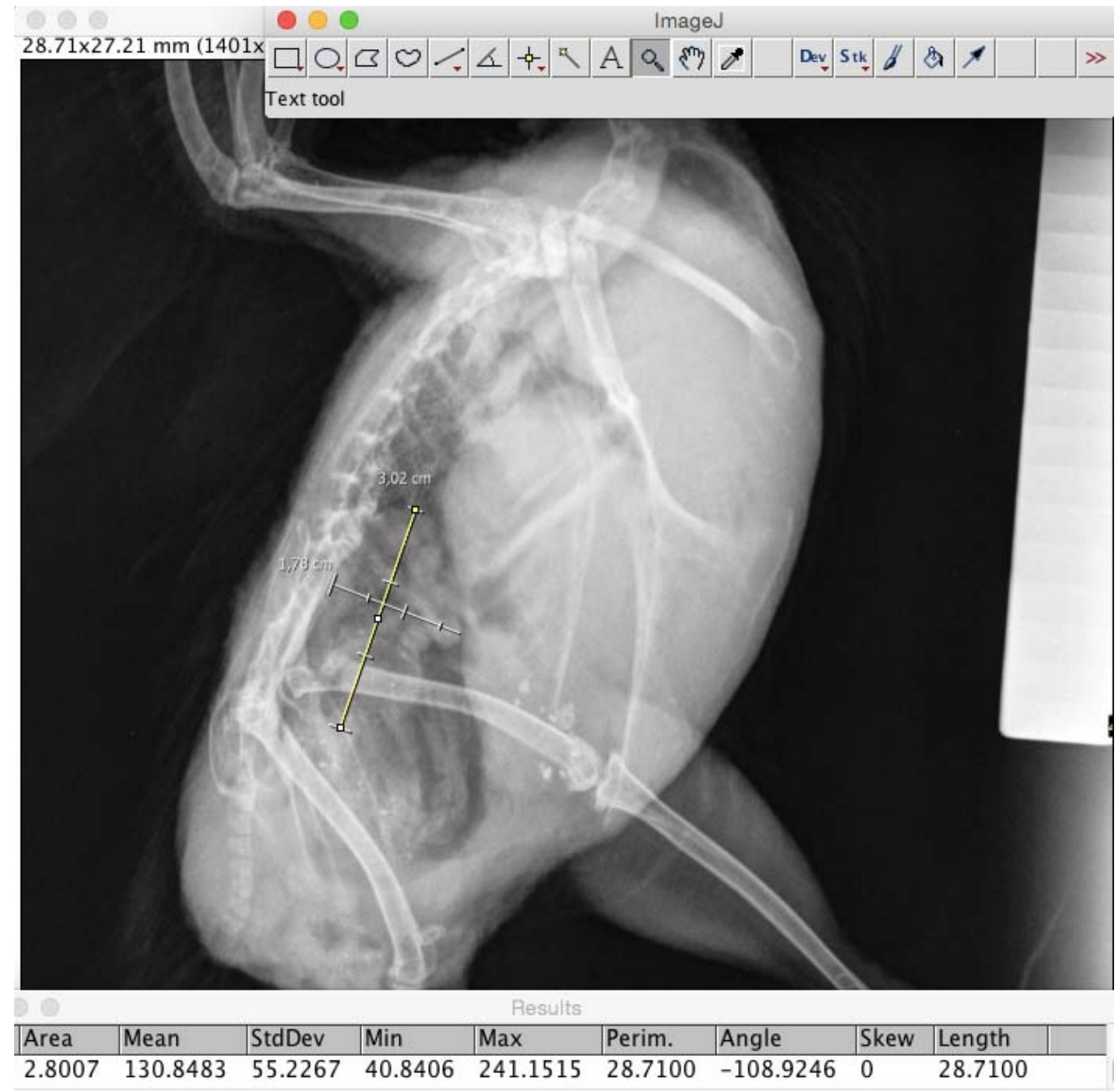

Figure 3. A - Setting the scale by determining in ImageJ software that a penetrometer stair step has $5 \mathrm{~mm}$. B - Radiography of a Japanese quail with the measurement of the ovary length (arrows) and height. The numbers correspond to the measurements obtained by the X-ray machine. $\mathrm{C}$ - Ovarian measurement results generated by ImageJ software.

The laying quails' ovarian length means $(28.88$ $\mathrm{mm} \pm 8.09 \mathrm{~mm})$ were significantly higher $(\mathrm{p}=$ $0.01)$ than the non-laying quails' ovarian length $(15.99 \mathrm{~mm} \pm 3.23 \mathrm{~mm})$, as the ovarian height means were also higher $(\mathrm{p}=0.02)$ in laying quails $(14.97 \mathrm{~mm} \pm 5.21 \mathrm{~mm})$ than in non-laying ones $(8.63 \mathrm{~mm} \pm 4.10 \mathrm{~mm})$ (Fig. 4$)$. 


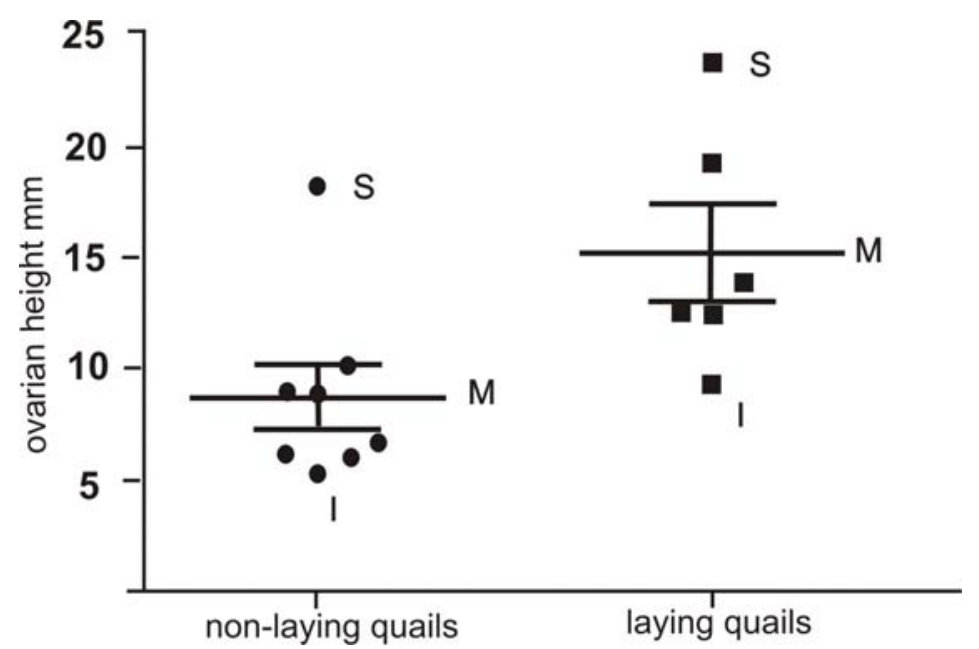

Figure 4. Dispersion graph mixed with box-plot graph showing the difference between ovarian height from laying and non-laying quails. I = inferior limit; $\mathrm{M}=$ mean; $\mathrm{S}=$ superior limit.

Approximately half of the quails stopped laying eggs after arriving at the University and the quails that resumed to lay eggs did not have posterior interruption of egg production.

\section{DISCUSSION}

There are reports that say the decrease of the photoperiod can cease egg production (Romagnano, 1996; Pye et al., 2001), there is no information about the necessary time of reduced photoperiod and the light conditions (light intensity, type of artificial light) to promote ovary involution and to stop egg production (Bowles, 2002; Rosen, 2012). In the period of the year with higher brightness, the weight of bird's ovary increases threefold and the weight of bird's oviduct increases 16 times (Follett et al., 1973), which suggests that a reduction by the same proportion could reduce reproductive complications (Hernandez-Divers, 2005) and behavior disorders due to reproductive frustration (Cubas and Godoy, 2007).

The results found in the present study showed that the use of 220-270 lux provided by artificial fluorescent lamps for Japanese quails during 36 days was sufficient to promote significant ovary involution, however the same illuminance used for 24 days was not enough to induce an expressive ovary reduction. Ovary involution, even if not definitive, could facilitate surgical procedures as ovariectomy and salpingohysterectomy, both recommended in chronic egg binding and overproduction of eggs
(Pye et al., 2001). Ovary involution could facilitate the surgical access in these procedures and reduce the blood supply for the region.

In this work, an intermediate photoperiod (12:12) and a short photoperiod (8:16) were utilized, according to Siopes and Wilson (1980) and Cassone (2015). In many species of birds, exposure to photoperiods longer than 11.5 hours/day results in rapid induction of the hypothalamo-hypophysial-gonad axis, causing development and growth of testes and ovarian follicles (Cassone, 2015). The intermediate photoperiod was thus used to stimulate follicular development of the control group birds (12h/24d) and enable comparison with the light restriction birds $(8 \mathrm{~h} / 24 \mathrm{~d}$ and $8 \mathrm{~h} / 36 \mathrm{~d}$ groups). The white and fluorescent lighting has been used as control by Yadav and Chaturvedi (2015), but with a brightness production of 100 lux, lower than that used in this study (220-270 lux). When we consider the application of the results for pet birds, it is necessary to pay attention to the fact that the fluorescent lamp is widely used all over the world and the brightness normally found in the home environment can vary between 100 and 200 lux (Brazilian regulation ABNT NBR ISO/CIE 8995-1) in addition to natural light to which they are exposed. Fluorescent light has been used to promote sexual maturity (Siopes and Wilson, 1980), so the use of fluorescent light associated with high brightness may have stimulated follicular development and hampered ovarian regression. Even with these conditions, significant ovarian regression in the group 
submitted to the brightness time restriction of 8 hours for 36 days was found.

The birds that stopped laying eggs after arrival at the HV-UFPR showed more stressed behavior, a fact observed through the excitement shown when people approached during food care and cleaning. Some of them did not return to laying eggs even when submitted to a 12-hour photoperiod.

There was a low correlation between the quails' weight and the ovary weight and between the quails' weight and the ovary length. This shows that the body weight does not influence the change of these variables. There is a lack of studies with female Japanese quails (Coturnix coturnix japonica) that relate body mass to ovary weight, but studies with male quails show low correlation between the birds' body mass and the testicular mass. However, moderate correlation between the quails' body weight and the length of the right testicle and strong correlation between the quails' body weight and the length of the left testicle were found (Lanna et al., 2013).

There was no availability for quails' radiographic evaluation at the beginning of the experiment; therefore, some data are missing. The high correlation observed between the radiographic ovary length and the direct ovary length shows that X-ray can be a useful tool to estimate ovarian size in addition to assisting diagnosis of reproductive diseases and disorders, as it has already been widely used (Rosen, 2012). The measurements of ovarian length and height can also show whether or not the bird is in the laying phase, even without the presence of an egg in the radiographic image.

The use of the milimetric stainless steel ruler as a measuring instrument at necropsy allowed an accurate comparison between radiographic and direct measurements, since the same software was used in both measurements. The software used admits the input of smaller than $0.1 \mathrm{~mm}$ measures and added a similar percentage of error for both methods.

It is important to consider that only decreasing photoperiod may not be enough to stop egg laying, since there are other variables that influence the reproductive cycle such as calorierich diet, presence of toys in the cage and pairing with humans (Bowles, 2002). There is also a need for studies with different species in an attempt to reproduce the results and to evaluate the time for ovary involution required for each species of bird.

\section{CONCLUSIONS}

Digital radiography is a useful tool to estimate the actual ovary length for Japanese quails (Coturnix coturnix japonica) and to indicate if the bird is in the laying phase according to ovarian length and height. An eight-hour photoperiod for 24 days is not enough to promote expressive ovarian regression, while the use of reduced photoperiod for 36 days promotes significant ovary involution in Japanese quail.

\section{REFERENCES}

BOWLES, H.L. Reproductive diseases of pet bird species. Vet. Clin. N. Am. Exot. Anim. Pract., v.5, p.489-506, 2002.

CASSONE, V.M. Avian circadian organization: a chorus of clocks. Front. Neuroendocrinol., v.35, p.76-88, 2015.

CUBAS, Z.S.; GODOY, S.N. Medicina e patologia de aves de companhia. In: GUILAR, R.; HERNANDEZ DIVERS, S.M.; HERNANDEZ DIVERS, S.J. (Eds.). Atlas de medicina, terapêutica e patologia de animais exóticos. São Paulo: Interbook, 2007. p.213-264.

DOMINONI, D.; QUETTING, M.; PARTECKE, J. Artificial light at night advances avian reproductive physiology. Proc. R. Soc. A.: Biol. Sci., v.280, 2013.

ECHOLS, M.S. Surgery of the avian reproductive tract. Semin. Avian Exotic Pet Med.,v.11, p.177-195, 2002.

EVANS, J.E.; SMITH, E.L.; BENNETT, A.T.D. et al. Short-term physiological and behavioural effects of high versus low-frequency fluorescent light on captive birds. Anim. Behav., v.83, p.2533, 2012.

FOLLETT, B.K.; HINDE, R.A.; STEEL, E.; NICHOLLS, T.J. The influence of photoperiod on nest building, ovarian development and luteinizing hormone secretion in canaries (Serinus canarius). J. Endocrinol., v.59, p.151$62,1973$. 
HERNANDEZ-DIVERS, S.J. Minimally invasive endoscopic surgery of birds. J. Avian Med. Surg., v.19, p.107-20, 2005.

KEMPENAERS, B.; BORGSTRÖM, P.; LOËS, P. et al. Artificial night lighting affects dawn song, extra-pair siring success, and lay date in songbirds. Curr. Biol., v.20, p.1735-1739, 2010.

LANNA, L.L.; SOARES, F.A.; SANTOS, T.M.; OLIVEIRA, J.N. Gonadosomatic index and correlations between testicular dimensions and weight in Japanese quail (Coturnix coturnix japonica) at 60 days old. Arq. Bras. Med. Vet. Zootec., v.65, p.955-960, 2013.

OLANREWAJU, H.A.; THAXTON, J.P.; DOZIER III, W.A. et al. A review of lighting programs for broiler production. Int. J. Poult. Sci., v.5, p.301-308, 2006.

PEES, M. Radiography. In: CHITTY, J.; LIERZ, M. (Eds.). Manual of raptors, pigeons and passerine birds. Texas: Woodrow House, 2008. p.114-120.

PEREIRA, R.J.G. Reprodução das aves. In: CUBAS, Z.S.; SILVA, J.C.R.; CATÃO-DIAS, J.L. (Eds.). Tratado de animais selvagens. 2.ed. São Paulo: Roca, 2014. p.2235-2269.
PEZOA POBLETE, P.C.; MOUSTACAS, V.S.; OLIVEIRA, C.H. et al. Follicular activity in ostriches (Struthio camelus) evaluated by ultrasonography, and its relation with the photoperiod and egg laying. Arq. Bras. Med. Vet. Zootec., v.65, p.1573-1576, 2013.

PYE, G.W.; BENNETT, R.A.; DAVIDSON, J. Endoscopic salpingohysterectomy of juvenile cockatiels (Nymphicus hollandicus). J. Avian Med. Surg., v.15, p.90-94, 2001.

ROMAGNANO, A. Avian obstetrics. Semin. Avian Exotic Pet, v.5, p.180-188, 1996.

ROSEN, L.B. Avian reproductive disorders. J. Exotic Pet Med., v.21, p.124-31, 2012.

SIOPES, T.D.; WILSON, W.O. Participation of the eyes in the photosexual response of Japanese quail (Coturnix response japonica). Biol. Reprod., v.23, p.352-357, 1980.

YADAV, S; CHATURVEDI, C.M. Light color and intensity alters reproductive/seasonal responses in Japanese Quail. Physiol. Behav., v.147, p.163-168, 2015. 